\title{
Publisher Correction: Enhanced energy-constrained quantum communication over bosonic Gaussian channels
}

\author{
Kyungjoo Noh (D, Stefano Pirandola (1) \& Liang Jiang (1)
}

Correction to: Nature Communications https://doi.org/10.1038/s41467-020-14329-6, published online 23 January 2020.

The original pdf version of this Article contained an error in Eq. (9) and in Eq. (25), where the domain of "max" function was incorrectly given as " $0 \leq 1$ " instead of " $0<\mathrm{x} \leq 1$ " and in Caption of Fig. 2, where the domain of "argmax" function was also given as " $0 \leq 1$ " instead of " $0<\mathrm{x} \leq 1$ ". The pdf has been updated to include these corrections. The original HTML version was correct and has not been changed.

Published online: 11 March 2020

(c) (i) Open Access This article is licensed under a Creative Commons Attribution 4.0 International License, which permits use, sharing, adaptation, distribution and reproduction in any medium or format, as long as you give appropriate credit to the original author(s) and the source, provide a link to the Creative Commons license, and indicate if changes were made. The images or other third party material in this article are included in the article's Creative Commons license, unless indicated otherwise in a credit line to the material. If material is not included in the article's Creative Commons license and your intended use is not permitted by statutory regulation or exceeds the permitted use, you will need to obtain permission directly from the copyright holder. To view a copy of this license, visit http://creativecommons.org/licenses/by/4.0/.

(c) The Author(s) 2020 